\title{
China's Soft Power in Tanzania: Opportunities and Challenges
}

\author{
Muhidin \\ J. Shangwe
}

\begin{abstract}
In recent years, China has embraced the idea of soft power with ever more keen interest. Today, soft power is Beijing's key strategy in international politics, albeit not in the way the concept is understood and applied in the West. However, this strategy can hardly be said to have yielded fruit in Africa despite China's growing visibility and presence over the last two decades. This article aims at probing this issue by examining how China's soft power is manifested in Tanzania. In an attempt to show that soft power is not entirely a new practice in international politics, the article first applies a historical perspective to illustrate that it has been part and parcel of Chinese diplomacy, long before the term was coined by Joseph Nye in 1990. The article then analyzes Chinese activities in Tanzania and how they have shaped perceptions of Tanzanians of China in the era of globalization. These activities are structured in line with three traditional sources of soft power as postulated by Nye, namely culture, political values and foreign policy. As a supplement to Nye's definition,
\end{abstract}

Muhidin J. Shangwe is Assistant Lecturer at the University of Dar es Salaam and currently Ph.D. candidate at East China Normal University. His address is Department of Political Science and Public Administration, University of Dar es Salaam, P. O. Box 35042, Dar es Salaam, Tanzania. He can also be reached at shangwez@yahoo.com.

(c) 2017 World Century Publishing Corporation and Shanghai Institutes for International Studies China Quarterly of International Strategic Studies, Vol. 3, No. 1, 79-100

DOI: $10.1142 / S 2377740017500026$ 
however, elements of hard power are also included in the article, such as the use of economic inducements to produce, bolster and wield soft power. In general, China has made headway in its soft power ambitions by gaining positive reviews in Tanzania. While the current achievement is crucial as an initial step, there is still a long way to go for China in consolidating its soft power. Although China has earned admiration in some quarters of Tanzanian society, it is still premature to assume that in the long run Beijing will continue to enjoy increasing soft power in the country. Indeed, in some cases, such admiration only exists in verbal recognition. In the meantime, activities that damage China's image have further complicated matters and undermined China's soft power in Tanzania.

Keywords: Chinese diplomacy; soft power; "China Model”; Sino-Tanzanian relations.

\section{Introduction}

Developed by Joseph Nye, the concept of soft power indicates that "a country may obtain the outcomes it wants in world politics because other countries - admiring its values, emulating its example, aspiring to its level of prosperity and openness — want to follow [it]." ${ }^{11}$ The core of Nye's definition is the idea that soft power co-opts, unlike hard power that is based on inducement and use of force. According to Nye, a country's soft power relies on three resources: its culture (in places where it is attractive to others), its political values (when it lives up to them at home and abroad), and its foreign policies (when they are seen as legitimate and having moral authority). ${ }^{2}$ Nye's definition has been criticized for lacking convincing explanations on the overlapping relationship between soft and hard power. Indeed, far from what Nye's central thesis posits, hard power can be used to attain soft power, too.

Although the concept of soft power was intended for American consumption, it has attracted enormous interest within China, so much so that it has become part of the country's grand power strategy. However, Chinese

${ }^{1}$ Joseph S. Nye, Soft Power: The Means to Success in the World (New York: Public Affairs, 2004), p. 5.

${ }^{2}$ Ibid., p. 11. 
scholars have broadened its concept to include economic inducement as an important source of soft power. For China, soft power is anything except military force. It includes not only popular culture and public diplomacy, but also more coercive economic and diplomatic levers like aid, investment, and participation in multilateral organizations. ${ }^{3}$ Due to the limitation of Nye's definition, this article includes aid, investment and trade in its criteria for assessing China's soft power in Tanzania. More importantly, the usage of soft power here is in the context of the behavioral approach that focuses on how power is used rather than on the power resources themselves. This approach was suggested by Li Mingjiang when he described soft power as the "soft use of power," since soft power resources can be used to coerce, much as hard power resources can be used to appeal and attract. ${ }^{4}$

\section{China-Tanzania Relations in Historical Perspective}

Tanganyika, the great bulk of today's Tanzania, established diplomatic relations with the People's Republic of China on December 9, 1961, the very same day that it gained independence. Former Chinese Premier Zhou Enlai visited Tanganyika in January 1964 to set diplomatic relations in motion. When Tanganyika faced a mutiny by its army in January that year, China acted promptly to provide military assistance. China's assistance was the first to be publicly accepted by the Tanganyikan government, marking the beginning of Beijing's support of the Tanzania People's Defense Force (TPDF) to this day. On April 26, 1964, Tanganyika and Zanzibar merged to form Tanzania. The union continued receiving support from China, which had also recognized the Revolutionary Government of Zanzibar immediately after it overthrew the Sultanate government on January 12, 1964. This move was part of China's pragmatic foreign policy, notwithstanding reluctance by other countries (like East Germany and Soviet Union) to recognize the merger. China's pragmatism started to pay off when Tanzania opened its embassy in Beijing in October 1964.

\footnotetext{
${ }^{3}$ Joshua Kurlantzick, Charm Offensive: How China's Soft Power Is Transforming the World (New Haven: Yale University Press, 2008), p. 6.

4"Soft Power: Nurture Not Nature," in Li Mingiiang, ed., Soft Power: China's Emerging Strategy in International Politics (Maryland: Lexington Books, 2009), p. 7.
} 
Tanzania, a frontline state in the liberation of Africa, naturally linked itself with China, the leader in the Third World and supporter of anticolonial movements. Numerous bilateral agreements were reached between the two countries, with Tanzania becoming one of the biggest recipients of Chinese aid in Africa. The landmark Tanzania-Zambia railway built by the Chinese is one of the biggest Chinese projects in Africa to this day. Others include the Ubungo Farm Implements Factory, the Mbarali Rice Farm, and friendship Mill Textile. This friendship, of course, has been in line with the broad political interests of China aiming at cementing its agenda in international politics. The restoration of the People's Republic of China (PRC)'s lawful seat in the United Nations (UN) was a result of this strategy by Beijing. At the announcement of the restoration, the Tanzanian representative to the UN, who had worked tirelessly to lobby for votes in support of China's quest for its UN seat, is said to have rejoiced in dancing.

The development of Sino-Tanzanian relations indicates elements of Beijing's soft power in the early times of their diplomatic contacts. The context within which these relations took place alludes to this point. Among other issues, Tanzania's decision to take the socialist route in 1967 in particular was not well received by Western countries. This happened after the country quarreled with West Germany, Britain, and the United States during the period between 1964 and 1965. Tanzania was striving to reduce dependency on Britain, a former colonizer whose presence in the country was still all too obvious. Even the construction of the Tanzania-Zambia railway happened in this context. The two countries approached Britain, the United States, Canada, West Germany, France, the Soviet Union, the World Bank, and the African Development Bank as they sought funds for the project, all to no avail. ${ }^{6}$ Only the Chinese defied the odds when they pledged support for the project, which was seen as too expensive and economically unsound. China decided to support the project because

${ }^{5}$ K. Mathews and Samuel S. Mushi, eds., Foreign Policy of Tanzania 1961-1981: A Reader (Dar es Salaam: Tanzania Publishing House, 1981), pp. 34-66.

${ }^{6}$ Martin Bailey, “Tanzania and China," in K. Mathews and Samuel S. Mushi, eds., Foreign Policy of Tanzania 1961-1981: A Reader. 
Tanzania represented a country that was principled, determined, antiimperialist and innovative. ${ }^{7}$ These attributes were similar to those of China during that time, making the friendship between the two nearly

China's soft power in

Tanzania in the

1960s-1970s was

mainly evident from

its economic

assistance and

development

experience. spontaneous.

When Tanzanian President Julius Nyerere visited China in 1968, as a sign of admiration, he insisted that he had gone there to learn. ${ }^{8}$ During this learning trip, Nyerere is said to have shown a keen interest in the Chinese model of development, seen as different from the inherited colonial model, which suggests that China's soft power came in part from the fact that Beijing had no colonial past in Tanzania and Africa. According to Martin Bailey, Nyerere was impressed by a number of things, including Chinese leaders' devotion to "serving the people" rather than the ruling elites; he was also impressed by Chinese people's frugality and he spoke against conspicuous consumption in Tanzania. Bailey argued that there appeared to be many similarities between China and Tanzania. Apart from a shared value of self-reliance and similar levels of rural development, Bailey observed that the Tanzanian government, just like its Chinese counterpart, introduced policies where manual and intellectual work was integrated. An example was given where things like establishing farms in schools, introducing national service for students in higher education and Nyerere's symbolic periods of physical labor in the country were instituted. ${ }^{9}$ Indeed, there has been debate within Tanzanian society over the extent to which Ujamaa policy was influenced by China. The mainstream opinion, and the one that Nyerere held, is that Ujamaa was a form of African socialism, an ideology derived from the experience of traditional African society. Nevertheless, there are also many others who believe that the policy was greatly influenced by China. Apart

${ }^{7}$ Joseph Kulwa Kahama, Sir George: A Thematic History of Tanzania Through His Fifty Years of Public Service (Beijing: Foreign Languages Press, 2010).

${ }^{8}$ Martin Bailey, "Tanzania and China," in K. Mathews, Samuel S. Mushi, eds., Foreign Policy of Tanzania 1961-1981: A Reader, p. 178.

${ }^{9}$ Ibid. 
from some interviewees who alluded to this, others have explicitly gone on record stating the proposition. ${ }^{10}$

Sir George Kahama, a cabinet minister and member of delegation during Nyerere's first trip to China, also spoke of the general feelings from their experience in the communist country. He talked of the delegation having "a feeling of incongruity as Tanzanian delegates were flown from Hong Kong to Beijing in the personal plane of Mao Zedong, leader of a country where equality of all people was proclaimed."11 As they arrived in Beijing, Sir Kahama explained how that incongruous feeling "changed to awe upon arriving in Beijing, no one seemed hungry and everyone seemed to have shoes on their feet and a house in which to live (emphasis added)."12 In particular, Kahama revealed that the delegation was deeply impressed by the country's organization through rural co-operatives and basic labor-intensive industries. $^{13}$

Sino-Tanzanian relations have continued to strengthen in the postCold War era. Not only has China become Tanzania's largest development partner, but Tanzania's centrality in Chinese broad interests has also been underscored. Two Chinese presidents - former President Hu Jintao in February 2009 and the incumbent President Xi Jinping in March 2013 have visited Tanzania. During the handover ceremony of Tanzania's 60thousand-seater national stadium funded by China on February 16, 2009 in Dar es Salaam, President Hu Jintao described the relationship between China and Tanzania as models for both China-Africa and South-South cooperation in his speech. ${ }^{14}$ Moreover, President Xi visited Tanzania immediately after he took office. Tanzania was his second stop after Russia, but

${ }^{10} \mathrm{~A}$ good example is a piece which appeared in a Tanzanian newspaper, which reads: “The Ujamaa policy was greatly influenced by Chinese socialism (the author's translation)." See "Maendeleo ya China, Tanzania tujifunze nini? [China's Development, What Should Tanzania Learn?]," Mwananchi Online, July 30, 2016 http://www.mwananchi.co.tz/Makala/-/ 1597592/2814142/-/r8fl0b/-/index.html.

${ }^{11}$ Kahama, Sir George: A Thematic History of Tanzania Through His Fifty Years of Public Service, p. 105.

${ }^{12}$ Ibid.

${ }^{13}$ Ibid.

14 “Chinese President Speaks Highly of China-Tanzania Ties," Xinhua News, February 26, 2009, http://news.xinhuanet.com/english/2009-02/16/content_10828650.htm. 
the first on the African continent, which reflected the profound long-term friendship between the two countries. President Xi called Tanzania "an old friend and a good friend of China," and said that the "China-Tanzania friendship was forged by the older generation of leaders including Chairman Mao Zedong, Premier Zhou Enlai and President Julius Nyerere." ${ }^{15}$ As a result of this friendship, China has enjoyed considerable favorability in Tanzania in the last few years (see Table 1). President Jakaya Kikwete of Tanzania even boldly claimed that he did not think China had a better friend in Africa than Tanzania. ${ }^{16}$

In the meantime, China's military presence in Africa has been increasing, notably on the east African coast where Beijing has sent soldiers as part of international anti-piracy efforts. Despite this trend, a Pew Research survey in 2007 found that Tanzanians were evenly split when asked about how China's growing military power affected their country. 41 percent thought it was a good thing for Tanzania, while another 41 percent thought it was a bad

Table 1. China's Favorability Ratings in Tanzania.

\begin{tabular}{lc}
\hline Year & Favorability \\
\hline 2007 & $70 \%$ \\
2008 & $71 \%$ \\
2014 & $77 \%$ \\
2015 & $74 \%$ \\
Average & $73 \%$ \\
\hline
\end{tabular}

Source: Compiled by the author from Pew's Global Indicators Database for 2007, 2008, 2014, and 2015. ${ }^{17}$

${ }^{15}$ Embassy of the People's Republic of China in the United Republic of Tanzania, "Xi Jinping Holds Talks with His Tanzanian Counterpart Kikwete, Agreeing to Develop a Comprehensive Cooperative Partnership Featuring Mutual Benefit and Win-win Results," April 12, 2013, http://tz.china-embassy.org/eng/topics/xjpzxftzt/t1030624.htm.

16“FT Interview: Jakaya Kikwete," Financial Times, November 7, 2007, https://www.ft. com/content/d8a07e28-72a3-11dc-b7ff-0000779fd2ac.

${ }^{17} \mathrm{Pew}$ Research Center, “Opinion of China,” http://www.pewglobal.org/database/ indicator/24/survey/8/. 


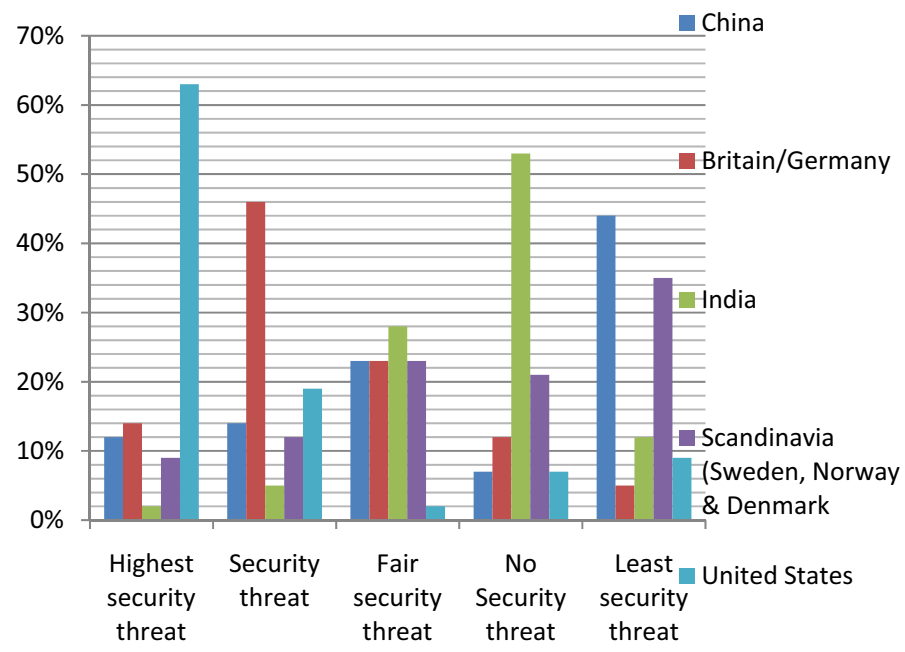

Fig. 1. Tanzanians' Perception of External Security Threats from Major Powers (Question: Which country among the following poses the highest security threat to Tanzania?).

Source: Field data by the author.

thing. ${ }^{18}$ When asked to rank countries in relation to the security threat they pose to Tanzania, students at the University of Dar es Salaam ranked China far behind the United States and other Western powers (see Fig. 1).

\section{Culture and Education as Traditional Soft Power}

In Tanzanians' eyes, the Chinese culture is attractive for its perseverance, despite decades of being under foreign domination. One respondent described the Chinese culture as "consistent" and expressed his admiration for the fact that Chinese people "love, value and protect" their culture. ${ }^{19}$ In addition, Chinese presence in Tanzania is manifested in the form of increasing cultural activities in the country. The annual Chinese New Year celebrations has become a common event since 2010, known as "Focus on Africa, Chinese New Year in Tanzania." Apart from the Tanzania National Chinese-Wushu (Kung Fu) Competition beginning in 2011, a TV series which tells the story of life in modern China, the Swahili-dubbed "Dou Dou

${ }^{18}$ Ibid.

${ }^{19}$ From focus group discussions with students at University of Dar es Salaam Confucius Institute. 
na Mama Wakwe Zake (Dou Dou and Her In-laws)," was launched by the Tanzania Broadcast Cooperation (TBC) in the same year. By 2015, there had been four Swahili-dubbed Chinese TV dramas aired in Tanzania. The other three were "Father's Wishes (Matumaini ya Baba)" and "Mother's Glorious Days (Maisha ya Mama)" in 2013, and "Let's Get Married" in 2015. The dubbing was usually done in China, which means Tanzanian artists involved were invited to Beijing and trained for the task. In an interview with Liu Dong, Cultural Councilor at the Chinese embassy in Tanzania, he expressed satisfaction of the way Tanzanian artists and people as a whole took up opportunities. At the launching of "Father's Wishes" and "Mother's Glorious Days" on October 27, 2013, the Director of Culture from the Ministry of Information, Youth, Culture and Sports revealed that "Dou Dou and Her In-laws" was such a hit that the TBC had to rebroadcast it upon the viewers' requests. ${ }^{20}$ The popularity of these Chinese dramas in Tanzania comes from the fact that they are dubbed in Swahili, the national language of the country.

\section{The Chinese}

language, cuisine and TV dramas have gained increasing popularity among the Tanzanian people.
Tanzanians also encounter Chinese culture in the form of its cuisine. Currently, there are about 10 Chinese restaurants in Dar es Salaam, a significant development since there was none a few years ago. This author's observation is that whilst few locals patronized these restaurants before, the situation is slowly changing, as more and more people are exposed to Chinese cuisine. Those who have dined at these restaurants talk of Chinese food as being delicious and healthy. has increased. Some study the language to do business with the Chinese; other reasons, as one respondent explained, include the beauty of Chinese characters which [he said] are "artistic and pleasant to the eyes." ${ }^{21}$ The

20“Tamthiliya Mbili Za China 'Maisha Ya Mama' na 'Matumaini Ya Baba' Zazinduliwa Dar Es Salaam [Two Chinese TV Dramas 'Mother's Life' and 'Father's Hope' Launched]," October 17, 2013, http://swahili.cri.cn/141/2013/10/17/1s123701.htm.

${ }^{21}$ From focus group discussions with Tanzanian students at the University of Dar es Salaam Confucius Institute. 
Tanzanian government announced in 2015 that it was going to introduce Chinese language study in six secondary schools in the country starting from the following year. As Phase One of a special Chinese language pilot project, it was launched because the Ministry of Education, Science, Technology and Vocational Training had noted the importance of Chinese language as a subject in secondary schools, so that students could access opportunities available in China, including further education. ${ }^{22}$ So far, there are two Confucius Institutes in Tanzania, at the University of Dar es Salaam and the University of Dodoma respectively. China has further stepped up its commitment to this cause by constructing a "model school" for Chinese learners in primary schools.

China's educational investment has also been on the rise, especially in terms of scholarships offered by the Chinese government to foreign students in recent years, so that more Tanzanians are incentivized to study in China. According to Liu Dong, China offers 120 scholarships to Tanzanians every year, including those in the 20/20 arrangement, a collaborative program of exchanging students between 20 Chinese universities and 20 African universities. As of 2014, more than 1,400 Tanzanian students were studying in China. ${ }^{23}$ Most Tanzanian students on Chinese government scholarships are required to study the Chinese language for a year. Through personal communications with some of those in Shanghai, it is certain most of them are excited about learning the language. They feel that grasping the language makes their lives easier, as they are able to communicate with the locals. However, they also find the language difficult to learn; some even complain that they barely understand a thing during class sessions. This language difficulty has thus "scared" off some students, who prefer to study in the Western countries where they are taught in English, the second official language in Tanzania.

In a survey at the University of Dar es Salaam, it is observed that the United States is the most preferred destination for higher learning for Tanzanian students, followed by Scandinavian countries, namely Denmark, Norway, and Sweden. China is only surpassed by India as the least

22 “Six Secondary Schools Selected for Chinese Language Pilot Project," Daily News, January 4, 2016, http://www.dailynews.co.tz/index.php/home-news/45695-six-secondaryschools-selected-for-chinese-language-pilot-project.

${ }^{23}$ Interview with Liu Dong, Cultural Councilor at the Chinese Embassy in Tanzania. 


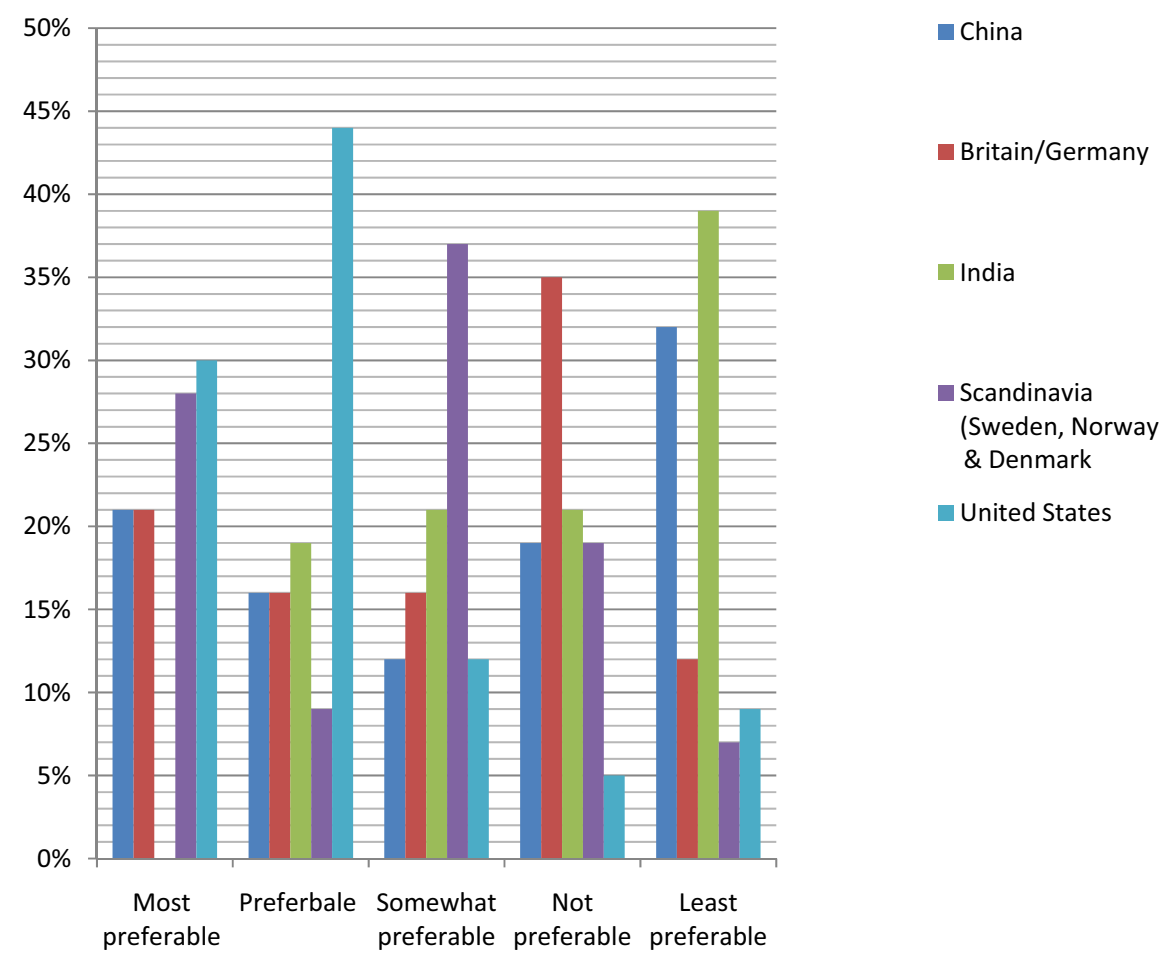

Fig. 2. Preferred Country for Further Studies amongst Tanzanian Students (Question: Which country among the following would you most prefer to go to for further studies?). Source: Field data by the author.

preferable destination. Therefore, it is assumed that most students would consider China after they have missed out opportunities to go to the United States or Scandinavian countries. Even some of those in the 20/20 arrangement felt reluctant to go to China. ${ }^{24}$ The oft-cited obstacle is the difficulty associated with learning the Chinese language. However, as Fig. 2 indicates, China is not doing poorly in terms of attracting Tanzanian students, given it is still new in this regard compared to Western countries. In fact, self-sponsoring students increasingly prefer China for affordability and usually enroll for English-taught courses.

${ }^{24}$ As a beneficiary of this arrangement, the author was once asked by the authorities of East China Normal University why they were not receiving doctoral students from the University of Dar es Salaam as per the agreement. Through personal communication it was found that some who had received this scholarship were reluctant to go to China, but preferred to study in the West instead. 


\section{Socio-political Values as Traditional Soft Power}

Critics of Chinese soft power tend to emphasize Beijing's lack of social and political capital in attracting people in other parts of the world. Indeed, apart from China's successful economic transformation, very little is known to Tanzanians about how the country is run, let alone its domestic social and political dynamics. There also seems to be a social and political distance between both countries, as none of Tanzania's opposition parties interviewed had any sort of link with political groups within China. The same applies to Tanzanian NGOs. Part of the reason is that the two countries have different values that define their political and social systems. For Tanzanian political parties, mainly the opposition, the single-party system of China is something undesirable. As for Tanzanian civil society, China's highly centralized political system is perceived as contravening the social space within which civil society flourishes.

Joshua Ramo coined the term "Beijing Consensus" to describe the Chinese model of development vis-à-vis the infamous Washington Consensus. The Chinese, however, prefer the term "China Model" to "Beijing Consensus" for modesty's sake and also to escape the revisionist tag. Ramo described the Beijing Consensus, used herein as China Model, as built on three assumptions. ${ }^{25}$ First, innovation is the key to development, and the old model of starting with simpler technologies and then seeking more complex ones should not be taken for granted. Second, chaos is a constant in economic development and should never be overlooked. Thus the government should not only focus on traditional measurements like per capita GDP, but also the quality of life such as sustainability and equality - in fact, chaos management has become the paramount concern during the development process. Furthermore, the idea that a single economic reform approach can solve every development problem is rejected, as well as the idea of shock therapy to push a planned economy to liberal economy overnight. The third assumption is the need for states to develop in their own ways, free from unwelcomed international interference. Self-determination should be a right of all states in the development process, a direct

${ }^{25}$ Marc Lanteigne, Chinese Foreign Policy (Oxford: Routledge, 2009), pp. 43-46. 
swig at the Washington Consensus' great power intrusion and an extension of China's traditionally conservative views of state sovereignty. The Beijing Consensus is thus, as Ramo observed, an economic as well as a political

The Chinese model

of development provides lessons for

Tanzania as the country reflects on its largely failed neoliberal policies. model.

The successful economic reforms, which have propelled China to become the world's second largest economy, have presented China with a great opportunity for economic prosperity. As such, some Tanzanians believe that the country can learn a lot from its Asian counterpart. Indeed, the success of the China Model seems to have won admiration within the Tanzanian academia as well as across the political spectrum. In the wake of China's successful economic reforms, some Tanzanian scholars are proposing that the country should have a serious conversation on economic models that will define its development agenda. ${ }^{26}$ This call comes at a time when the country already has an economic model in the form of neoliberalism. It indicates that there is resentment surrounding the neoliberal direction the country took nearly three decades ago, for not much progress has been achieved since then. Mwesiga Baregu, a prominent academic and professor of international relations in Tanzania, echoed Zimbabwean President Robert Mugabe's Look East policy in an interview. He argued that the Chinese model of development is an inspiration to African countries who are still charting out economic models suitable for their conditions. For many in Tanzania, the Beijing Consensus presents an alternative model of development vis-a-vis the failed neoliberal policies as prescribed by the Washington Consensus.

In support of the China Model, Professor Ibrahim Lipumba, a renowned Tanzanian economist and politician, wrote a series of articles about "China's economic development and lessons for Tanzania" which was

${ }^{26}$ Interview with Professor Severine Rugumamu of the Institute of Development Studies, University of Dar es Salaam. There are also similar sentiments by $\mathrm{Ng}^{\prime}$ wanza Kamata, see "Perspectives on Sino-Tanzania Relations," in Seifudein Adem, ed., China's Diplomacy in Eastern and Southern Africa (Oxford: Taylor \& Francis Ltd, 2014), pp. 87-106. 
published in the country's best-selling daily newspaper Mwananchi. ${ }^{27}$ His argument was that Tanzania had a lot to learn from China, including the Chinese government's decision to retain control over the financial and banking sectors while opening up its economy. Giving priority to infrastructure building, allowing state-owned companies to compete with their private counterparts, and establishing special economic zones were all seen as practical policy experience that Tanzania could emulate. ${ }^{28}$

China was frequently mentioned by the ruling party's presidential candidate John Pombe Magufuli during the 2015 general elections, whose message was that China provided lessons for Tanzania to advance its development agenda. Nevertheless, there has not been concrete policy decisions toward the China Model. For instance, Tanzania's financial sector, mentioned as key in the China Model, is still in the hands of the private sector, sometimes as a joint venture of both the private and public sectors. Thus, it is fair to say that the three core assumptions of the China Model are not yet evident in Tanzania's development policy.

\section{Foreign Policy as Traditional Soft Power}

Chinese foreign policy is rooted in its Five Principles of Peaceful Coexistence as articulated in the Panchsheel Treaty in 1954. These principles are: (1) mutual respect for each other's territorial integrity and sovereignty; (2) mutual non-aggression; (3) mutual non-interference in each other's internal affairs; (4) equality and cooperation for mutual benefit; and (5) peaceful coexistence. In this spirit, China has forged a relationship of mutual benefit with Tanzania. In theory and practice, it means that China treats every nation as an equal partner, regardless of its size and economic strength. For Tanzania, this goes back to the early years after independence. At a state banquet during Zhou Enlai's visit to Tanzania in 1965, President Nyerere

${ }^{27}$ Professor Ibrahim Lipumba is the former Chairman of the opposition party Civic United Front and a four-time presidential candidate. He is considered one of the best economists in the country.

28"Maendeleo ya uchumi wa China, Tanzania tujifunze nini? [China's Development, What Should Tanzania Learn?]," Mwananchi, July 23, 2015, http://www.mwananchi.co.tz/Makala/ Maendeleo-ya-uchumi-wa-China-Tanzania-tujifunze-nini--1/-/1597592/2803926/-/ j83hb2/-/index.html. 
extended his appreciation that China treated Tanzania as an equal partner, despite China being a huge country. He described the relationship between the two countries as "a friendship between most unequal equals." ${ }^{29}$

One of the most often mentioned argument across the world - Africa in particular - is how China treats its international partners. Some have even argued that "China, unlike the West, treats us like adults. The West treats us like children who should be taught how to develop their countries." ${ }^{30}$ In practice, this has been achieved through subtle gestures, such as the respect accorded to leaders of other countries when they visit China, no matter how small those countries are. For instance, a decade after the motorcycle escort for foreign leaders was brought to a halt on January 1 , 2004, China resumed the practice on October 21, 2014. ${ }^{31}$ The fact that the first foreign leader to be given this treatment after the resumption was President Jakaya Kikwete of Tanzania could be seen as a mere coincidence, but in the world of diplomacy, it could also signal the importance that China attaches to Tanzania. In another case, China was one of the first countries to congratulate the incumbent Tanzanian President John Magufuli after he assumed office. The timing was crucial, as Western governments were still reluctant to endorse Magufuli after the opposition had claimed that results were rigged. Even more, when the Tanzanian government announced in July 2016 that it was planning to effectively move the capital from Dar es Salaam to Dodoma, China quickly supported the plan and pledged to move its embassy accordingly.

China's Five Principles and conduct of its foreign policy have been welcomed by Tanzania, as they comply with the country's ideals expressed in its foreign policy. As an official in the Ministry of Foreign Affairs put it in an interview, the Five Principles and Chinese foreign policy in general are consistent with Tanzania's aspirations, which have always demanded a just international system. Given China's growing stature in the international realm, Tanzania feels that Beijing is a very important "friend" in making its

${ }^{29}$ Martin Bailey, "Tanzania and China," in Mathews and Mushi, eds., Foreign Policy of Tanzania 1961-1981: A Reader, p. 184.

${ }^{30}$ Conversation with an anonymous Tanzanian diplomat.

31 “China Resumes Motorcycle Escorts for Foreign Leaders," China Daily, October 22, 2014, http://www.chinadaily.com.cn/china/2014-10/22/content_18784577.htm. 
voice heard in the struggle for global justice. ${ }^{32}$ It is important to note that the support between the two countries is mutual, as Beijing also seeks Tanzania's help whenever in need.

Despite the positive review, Chinese diplomacy has come under scrutiny at times. It is observed that China has been striving to improve its diplomacy by different means, including training its officials on how to handle and carry out their diplomatic duties. While it is argued that Beijing has improved significantly in that respect, an incident of diplomatic gaffe involving a top Chinese diplomat in Dar es Salaam did occur, ${ }^{33}$ which

The dynamics of Tanzanian domestic politics challenges China's long-standing diplomatic principles. resulted in an uproar, particularly from the main opposition party Chama cha Demokrasia na Maendeleo (CHADEMA). The government also condemned the incident saying that it was taking diplomatic action against the envoy, ${ }^{34}$ though details of the measures taken were not revealed. The close friendship between Chama Cha Mapinduzi (CCM), the ruling party, and the Communist Party of China (CPC) has stopped the opposition from forging similar ties with the CPC. ${ }^{35}$ In fact, the opposition accuses China of being biased toward the ruling party. ${ }^{36}$ The comradeship between CCM and the CPC is illustrated in the 2015 elections where the CCM manifesto mentioned China three times, all in the context of positive portrayal of the cooperation between the two countries.

\footnotetext{
${ }^{32}$ Interview with an official at the Tanzania's Ministry of Foreign Affairs and International Cooperation.

${ }^{33}$ For more details of the incident, see "Balozi wa China matatani [Chinese Ambassador in Trouble]," Nipashe, September 17, 2013, http://www.ippmedia.com/frontend/?1=59372.

34 "Politicking' Chinese Envoy Runs into Trouble in Tanzania," Africa Review, September 18, 2013, http://www.africareview.com/News/Politicking-Chinese-envoy-runs-intotrouble-in-Tanzania/-/979180/1997344/-/p6tj5kz/-/index.html.

${ }^{35}$ Interview with Wilbrod Slaa, CHADEMA's Secretary General at the time of interview.

${ }^{36}$ The Civic United Front (CUF), the main opposition in Zanzibar, accused China of "political rent-seeking behavior" by endorsing fiercely disputed elections in 2015 as free and fair. See "CUF Yaitolea uvivu China [CUF Slams China],"Mwanahalisi, April 1, 2016, http:// mwanahalisionline.com/cuf-yaitolea-uvivu-china/.
} 
In contrast, the CHADEMA Manifesto, which represented a coalition of four opposition parties, mentioned China only once in the context of illegal logging business. This highlights the fact that neither of the two major opposition parties in Tanzania has any formal links with China, or its political groups. This scenario amounts to a feeling that the close ties between China and Tanzania are framed within the friendship between CCM and the CPC, and that other political stakeholders are being sidelined. Therefore, it is safe to say that China's image has not been positive in this regard, as far as the opposition is concerned.

\section{China's New Sources of Soft Power: Investment, Trade, and Aid}

It is doubtless that Chinese products have found their way into Tanzania as they have elsewhere on the continent, thanks to increasing commercial activities between people of the two countries. More and more Tanzanian traders are traveling to China (6,000 in 2014 alone), and they see China as a great business opportunity. They argue that Chinese products are suited for the Tanzanian market because they offer a wide range of prices. The Tanzanian market is one of low-income people with meager purchasing power, and thus cheap Chinese goods are welcomed by the majority of Tanzanians. ${ }^{37}$ This, in turn, is benefiting traders as well as adding to the trade volumes between both countries.

The relationship is also reflected in the number of agreements China and Tanzania have signed in recent years. During a state visit to Tanzania in March 2013, President Xi Jinping and President Jakaya Kikwete signed at least 19 agreements reportedly worth more than US\$6 billion. ${ }^{38}$ One newspaper described Xi's visit as "showering blessings on Tanzania." ${ }^{39}$ These agreements cut across a broad spectrum of development, and in most cases they are purely business deals. Meanwhile, China has chosen

\footnotetext{
${ }^{37}$ Focus group discussions with Tanzanian traders who import goods from China at Kariakoo Market.

38 "China Drops Anchor in Tanzania," Mail \& Guardian, October 4, 2013, http://mg.co. za/article/2013-10-04-00-china-drops-anchor-in-tanzania/.

39 "Rais Xi Jinping kuipatia Tanzania neema [President Xi Jinping to Shower Blessings on Tanzania]," Mwananchi Online, March 23, 2013, http://mobile.mwananchi.co.tz/Habari/ 1597580-1728808-format-xhtml-a1lfaa/index.html.
} 
Tanzania along with Mozambique and Ethiopia as models of Chinese investment on the African continent. This five-year program will see 100 Chinese industries established every year over a period of five years, which means 500 industries in total. The idea is to make Tanzania a Chinese industry hub. ${ }^{40}$ In a move aimed at boosting Tanzania's infrastructure, China is supporting the construction of $\$ 10$-billion Bagamoyo mega port, touted to be Africa's largest ultra-modern port. ${ }^{41}$

Data from the Chinese Ministry of Commerce indicate that the number of international contracts won by Chinese companies in Tanzania rose from US\$ 0.3 billion in 2003 to US\$ 1.7 billion in 2013. ${ }^{42}$ Also, the Tanzania Ministry of Finance bulletin shows that the disbursement of Chinese loans increased from US\$299 million in 2010, to US\$ 743 million in 2012 and US\$ 1.4 billion in 2015; from 2010 to 2015, the cumulative disbursement reached over US\$ 8.3 billion, and the China Exim Bank and Beijing's ZTE made a US $\$ 300$ million loan to finance projects in Tanzania in the same period. ${ }^{43}$ This massive injection of funds into Tanzania in the forms of aid and investment has led Jean-Pierre Cabestan and Jean-Raphael Chaponniere, co-authors of a recent report on Sino-Tanzanian relations, to conclude that "China has gained influence in Tanzania through trade in goods and services (construction) and Chinese investment will probably increase." ${ }^{44}$ In fact, China's influence in Tanzania is beginning to surpass that of other major powers. The 2015 Afrobarometer survey showed that 40 percent of Tanzanians thought China had more influence in Tanzania than the United States (31 percent), South Africa (6 percent), United Kingdom (5 percent), India (4 percent), and international organizations (1 percent). More

40 “Sino-Tan Relations Strengthened under Kikwete," The East African, January 25, 2014, http://tz.china-embassy.org/eng/sgdt/t1253762.htm.

41 “China: Tanzania's Biggest Development Partner," The East African, January 25, 2014, http://www.theeastafrican.co.ke/news/China-Tanzania-biggest-development-partner-/-/ 2558/2160314/-/wmunsez/-/index.html.

${ }^{42} J e a n-P i e r r e ~ C a b e s t a n$ and Jean-Raphael Chaponniere, "Tanzania-China All-weather Friendship from Socialism to Globalization: A Case of Relative Decline," Center for Chinese Studies Discussion Paper, May 2016, http://www.ccs.org.za/wp-content/uploads/2016/05/ CCS_DP_1_2016_TANZANIA-CHINA-ALL-WEATHER-FRIENDSHIP-FROM-SOCIALISMTO-GLOBALIZATION.pdf.

${ }^{43}$ Ibid., pp. 21-22.

${ }^{44}$ Ibid. 
Table 2. Investments with Chinese Interests from 1990 to January 2015.

\begin{tabular}{|c|c|c|c|c|}
\hline & Sector & Number of Projects & Jobs & Total Investment (US\$ Mil.) \\
\hline 1 & Agriculture & 14 & 7,591 & 125.54 \\
\hline 2 & Telecom & 5 & 1,426 & 484.94 \\
\hline 3 & Manufacturing & 394 & 60,542 & 1803.77 \\
\hline 4 & Natural Resources & 8 & 376 & 18.31 \\
\hline 5 & Transportation & 39 & 4,168 & 156.36 \\
\hline 6 & Services & 22 & 1,436 & 152.22 \\
\hline 7 & Tourism & 50 & 2,570 & 98.75 \\
\hline 8 & Computers & 1 & 40 & 33.23 \\
\hline \multirow[t]{2}{*}{9} & Commercial Buildings & 60 & 3,512 & 510.3 \\
\hline & Total & 593 & 81,661 & $3,383.42$ \\
\hline
\end{tabular}

Source: Tanzania Investment Center, 2015.

importantly, 70 percent of Tanzanians thought that China's influence was positive. $^{45}$

While there is data discrepancy depending on the source, 2013 data from the Chinese Ministry of Finance indicated that China could have become Tanzania's largest investor. In 2013, the Ministry's data put Chinese investment in Tanzania at US\$ 2.1 billion. $^{46}$ According to the Tanzania Investment Center, since 1990 there have been 593 projects in Tanzania with Chinese investment. These projects cover various sectors, with manufacturing sector leading the lot. In the process, a total of $\$ 3.3$ billion has been invested. Table 2 illustrates these figures in relation to jobs created.

Trade volumes between the two countries have also increased drastically. At the Tanzania-China Investment Forum in Beijing on 22 October, 2014, it was revealed that in 2007, the total trade volume between China and Tanzania was US\$ 290 million, of which China's export was US\$ 180 and import US\$ 110 million. However, in 2013, the bilateral trade increased over 20 times to $\$ 3.7$ billion, among which about 80 percent went to China. ${ }^{47}$ It has also been revealed that in 2014 alone 6,000 people from

${ }^{45}$ Afrobarometer, “China Influence Seen as Strong, Positive in Tanzania," February 25, 2015, http://www.afrobarometer.org/press/china-influence-seen-strong-positive-tanzania.

${ }^{46}$ Cabestan and Chaponniere, "Tanzania-China All-weather Friendship from Socialism to Globalization: a Case of Relative Decline."

${ }^{47}$ Embassy of the People's Republic of China in the United Republic of Tanzania, "SinoTan Relations Strengthened under Kikwete," April 10, 2015, http://tz.china-embassy.org/eng/ sgdt/t1253762.htm. 
Tanzania went to China to do business, and the country attracted private capital of over $\$ 2.5$ billion and loans of $\$ 1.9$ billion from China. Over the years, Tanzanians traveling to China particularly for educational and business purposes have increased significantly. This has been enhanced by China's and Africa's commitment to further people-to-people interactions in areas such as education and culture. In the Beijing Declaration of the Forum on China-Africa Cooperation (2009), ministers from China and African countries declared,

\begin{abstract}
We decide to vigorously promote further China-Africa cooperation in the economic, trade, financial, agricultural, medical care and public health, scientific and technological, cultural, educational, human resources development, transportation, environmental, tourism, and other areas on the basis of the principles enshrined in this declaration and the Program for China-Africa Cooperation in economic and social development adopted at the Forum so as to promote the common development of China and Africa. $^{48}$
\end{abstract}

As a result of a myriad of Chinese economic activities in areas of development aid, investment and bilateral agreements between the two countries, China has enjoyed positive reviews as it is seen to be more supportive than other countries. For instance, when asked which country has been the most helpful to Tanzania, students at the University of Dar es Salaam overwhelmingly ranked China as the most helpful country, far ahead of the United States and erstwhile colonial powers like Britain and Germany, among others (see Figure 3).

Despite this development, China's image has been stained by reports of Chinese nationals involved in illegal activities. The illegal ivory trade is where China's image has suffered the most. For example, an incident

China's soft power is undermined by reports of Chinese nationals involved in illegal activities in Tanzania.

${ }^{48}$ Forum on China-Africa Cooperation, Beijing Declaration of the Forum on China-Africa Cooperation, September 25, 2009, http://www.focac.org/eng/ltda/dyjbzjhy/DOC12009/ t606796.htm. 


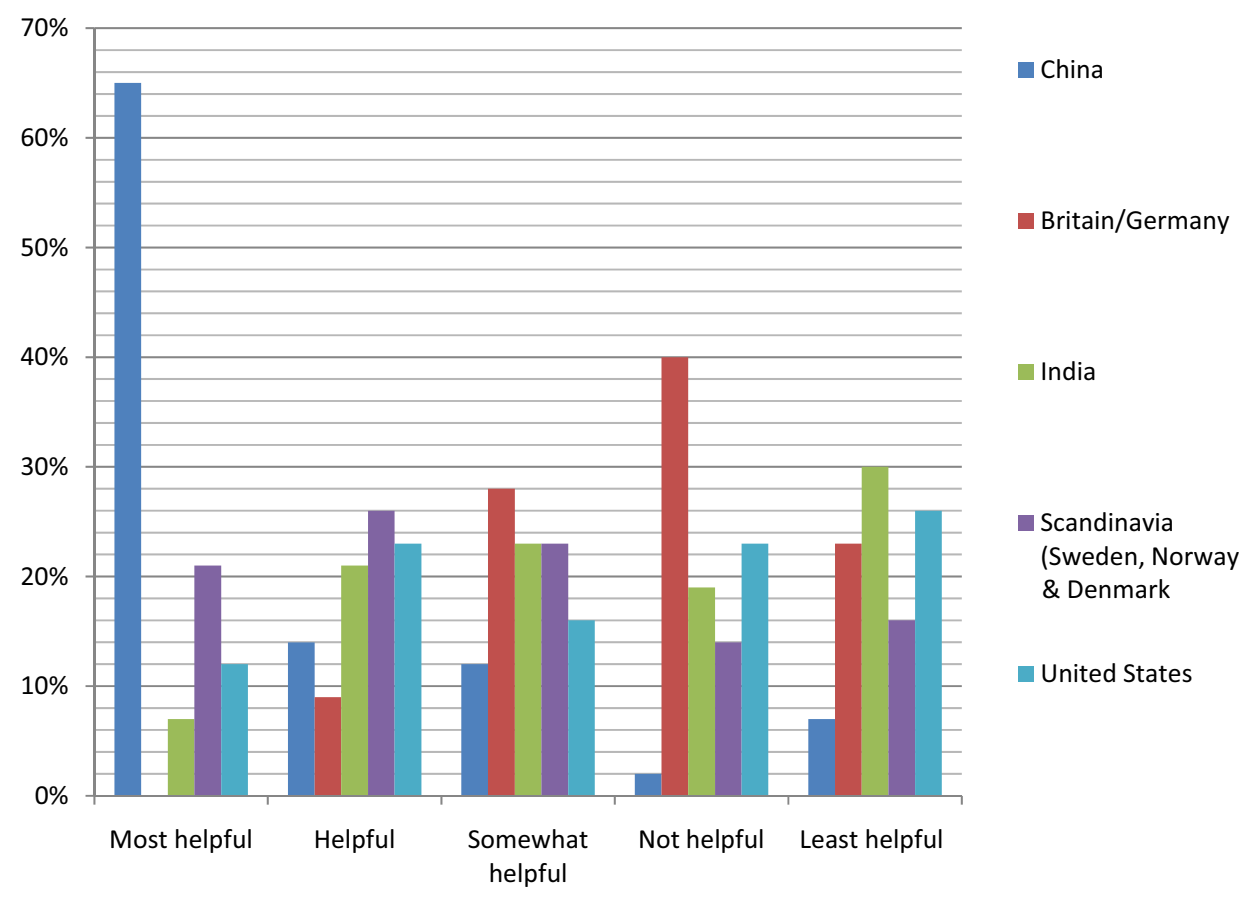

Fig. 3. Ranking Results of Countries Viewed as most Helpful toward Tanzania (Question: Which country, do you think, has been the most helpful to Tanzania and thus should have closest relations with it?).

Source: Field data (2014)

was reported in the media on November 3, 2013, when the Tanzanian government seized 706 elephant tusks from the hands of three Chinese nationals in Dar es Salaam. ${ }^{49}$ Two years later, a Chinese businesswoman, notoriously known as the Queen of Ivory, was arrested in Dar es Salaam for allegations of illegal ivory trade. ${ }^{50}$ Chinese companies in Tanzania have also made headlines for their mistreatment of local workers. In July 2016, there emerged reports accompanied by pictures of a Tanzanian worker being flogged by his Chinese employers at the Nyamahuna gold mines in Geita region. The accused Chinese national was arrested and charged. The

49"Shehena pembe za ndovu yakamatwa Dar [Ivory stockpiles seized in Dar]," Mwananchi, November 3, 2013, http://www.mwananchi.co.tz/habari/Kitaifa/Shehena-pembe-za-ndovuzakamatwa-Dar-es-Salaam/-/1597296/2058240/-/t10osh/-/index.html.

50“Arrest of China's 'Queen of Ivory' Welcomed," China Daily, October 12, 2015, http:// usa.chinadaily.com.cn/epaper/2015-10/12/content_22162517.htm. 
incident prompted the Minister for Home Affairs to visit the mining site, only to find out that the number of Chinese workers at the mine stood at 100 although only 28 had obtained permission from the Immigration Department. ${ }^{51}$ There have also been reports of corruption involving Chinese companies when bidding for tenders, allegations that were given weight when the Chinese envoy to Tanzania admitted that some Chinese people were indeed indulging in corruption and other "bad habits" which would tarnish the image of China. ${ }^{52}$ Following such tensions, on January 6, 2011, the government of Tanzania through its Deputy Minister of Trade, Industry and Marketing issued a 30-day ultimatum for illegal petty traders operating in the country's main market Kariakoo to vacate.

\section{Conclusion}

China has managed to accumulate considerable soft power in Tanzania in the last decade. Nevertheless, as shown in this article, Beijing's soft power may well date back to the early years of independent Tanzania. Currently China's appeal for many Tanzanians is a result of economic opportunities that Beijing presents. This has been the overriding source of Chinese soft power as Tanzanians look to benefit from the world's second largest economy. Against this trend is the fact that Chinese soft power is still in its infancy. It means that more needs to be done if Beijing truly wants to invest in its soft power, so that other resources such as culture and political values can command similar attraction. To this end, China will be compelled to address issues that tarnish its image in Tanzania, mainly illegal activities committed by Chinese nationals. In the meantime, politically, it is difficult to project how this will play out with Tanzania being a multiparty democracy, especially when a culture of political pluralism is taking root. While China remains an attractive partner to the ruling party CCM, any change of regime that will put another party in power in the future is likely to impact soft power elements in the political spectrum of Sino-Tanzanian relations.

51 “Illegal Gold Miners Identified in Geita,” Daily News, July 30, 2016, http://www. dailynews.co.tz/index.php/home-news/52171-illegal-gold-miners-identified-in-geita.

52 “Chinese Bribe in Tanzania, Admits Envoy," The Citizen, July 15, 2014, http://www. thecitizen.co.tz/News/national/Chinese-bribe-in-Dar-admits-China-envoy/18403922384042-q6ndijz/index.html. 